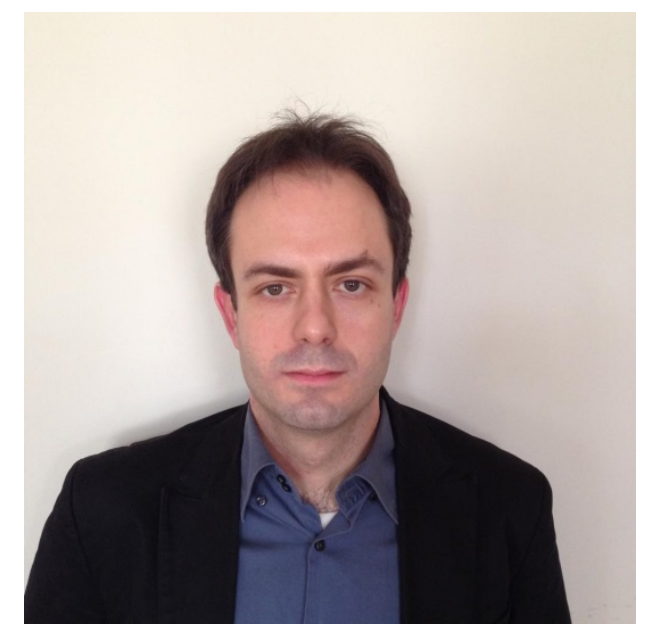

Guido Sechi,
PhD, Assistant Professor
and Researcher,
Department of Human Geography,
University of Latvia
Riga, Latvia
guidosechi78@gmail.com

Co-authors: Zaiga Krisjane, Maris Berzins

Department of Human Geography, University of Latvia

Dmitrii Zhitin

Department of Economic and Social Geography, Saint Petersburg State University

DOI 10.31554/978-5-7925-0571-1-2019-2-166-170

\title{
SOCIAL SEGMENTATION IN SUBURBANIZATION AFTER TRANSITION: A COMPARATIVE ANALYSIS OF SAINT PETERSBURG AND RIGA
}

This study consists of a comparative analysis of suburbanization patterns and their relations with socio-spatial segmentation and segregation dynamics in the functional areas of St.Petersburg and Riga, based on quantitative secondary socioeconomic data available at neighborhood and municipal level. Results show similar patterns of suburbanization and segmentation in the two case studies, and a significant connection between the two phenomena. At the same time, some significant differences are found out, depending on the demographic, economic, and market demand specificities of the two countries and cities. Finally, an integration of the proposed meso level analysis with multi-scalar perspectives and an extension of the comparative perspective to Soviet planned cities is proposed.

Keywords: post-Soviet suburbanization; socio-spatial segmentation; spatial inequality; comparative analysis; meso level analysis.

The study of socio-spatial dynamics and inequality in post-socialist transformation in Central-Eastern Europe and former Soviet Union cities 
constitutes an important branch of transition studies. Open issues in this domain range from the definition of theoretical frameworks to data availability and methodological approaches. As for the former aspect, traditional assumptions heavily relying on path dependency explanations and linear narratives of modernization have been recently challenged by conceptualizations focusing on the 'hybrid' nature of post-socialist urban space. In this regard, it is argued that both multi-level/multi-scalar and comparative research approaches may shed a light on more complex transformation dynamics. These approaches are seen as beneficial in order to move from purely descriptive and inductive contributions to conceptual ones, and to address at the same time the common characteristics of state socialist heritage and post-socialist transition, and the contextual specificities of countries and cities.

One of the most commonly studied phenomena in the context of sociospatial transformation is suburbanization dynamics. Suburbanization was an almost non-existing phenomenon under state socialism, but it has been very relevant in the CEE and FSU region since the collapse of the socialist system. Indeed, many countries in post-socialist Europe are characterized by a de-urbanization trend that is uncommon in the contemporary world. Suburbanization in the region has been interpreted as a modernization dynamic. However, this phenomenon, strongly associated with housing market segmentation, often has a socio-economic class characterization, and has relevant implications in terms of socio-spatial differentiation and segregation. In this regard, several empirical studies carried out in CEE and FSU cities have found connections between suburbanization and social tensions, segregation and exclusion. Besides, these tendencies are also associated with the typical detrimental ecological and social effects of urban sprawl.

This study is an attempt at analyzing, in a comparative perspective, the suburbanization trends and dynamics which have taken place in the last 30 years in the two cities - St. Petersburg and Riga - which are the two largest post-Soviet urban centers in the Baltic sea region, and their implication and effects with regard to socio-spatial segmentation. The analysis is based on Population Census 2010-2011 and population register data from the 19912018 period, reflecting trends of suburbanization trends in terms of social status (education, occupation, wealth), and property value and development typology of inner and outer suburbs in the two cities' functional areas. We 
define as functional area the territory corresponding to the city as administrative unit plus outside municipalities located within 60 minutes distance from the city core by public transport. We identify typologies of inner and outer suburbs on the basis of their demographic trends, their average levels of socio-economic wealth, and their housing development characteristics. This approach allows to grasp suburbanization dynamics and characteristics in the two cities and their similarities and differences. Besides, it aims at providing indications for a meta-reflection on the usefulness of comparative approaches, the strengths and weaknesses of a meso-level analysis, and the rationale for it to be integrated with with micro and macro perspectives.

Overall, both cities in the post-soviet period have been characterized, broadly speaking, by population decrease in the inner historical core and Soviet mass housing areas, and an increase in inner and outer suburbs. These processes were often determined by a search for cheaper accommodation in the suburbs in the 1990s, but since the 2000s they are mostly driven by new housing development. In the last two decades, they appear to contribute significantly to socio-economic segmentation. In both investigated cases, a belt of average wealthy satellite municipalities bordering city limits surrounded by less wealthy municipalities is observed, whereas, within city limits, wealthy inner suburbs are mostly associated with historical preSoviet prestige areas and low-density new housing development areas. Next to this, there are also relevant differences, which reflect different characteristics at urban, regional, and national level in terms of spatial and economic structure, demographic trends, and housing market demand. In Riga, a significantly sharper population decrease in the city proper and increase in outer suburbs (satellite residential municipalities) is observed, whereas in St.Petersburg the population increase in most of the outer suburbs bordering the city goes together with stable levels in most districts of the city proper, where the overall population change is positive since 2003, mostly due to internal and foreign immigration. Besides, post-2000 housing development-driven suburbanization in St. Petersburg is more heterogeneous in socio-economic terms, whereas in Riga the phenomenon is generally related to the middle-upper class. This reflects a higher heterogeneity of typologies of suburban housing development in the Russian case, with high-rise housing and high-density micro-district development mostly aimed at the lower-middle class, and villa-type housing aimed at the upper 
classes. In Riga, private and low-rise housing targeted at the middle-upper class predominate in suburban real estate development. The third main difference relates to the economic and labor structure of functional area municipalities. In Riga region, the wealthier belt consists of almost purely residential municipalities, where the share of commuters to the city is close to $100 \%$. In St. Petersburg functional area, the typology of wealthier municipalities is more diverse, including both residential cottage areas and satellite towns, and industrial towns characterized by relatively successful economic activities and performance.

In general, the analysis finds evidence of suburbanization dynamics strongly contributing to segmentation, albeit in different forms, in both areas. These results provide with support for the implication that marketdriven suburban development is a significant enabler of functional transformation of space and socio-spatial segmentation and polarization in postSoviet cities. The comparison between the functional areas of the two cities shows in this regard both many similarities and many contextual differences. The latter, however, appear to be affected by overall economic, demographic, and market demand differences between the two countries and cities, rather than by a different political-ideological logic and different strategic choices.

Overall, it can be said that the adopted comparative approach is able to provide with significant insights about the characteristics of suburbanization and its socio-spatial implications and effects in post-soviet cities. However, in order to understand suburbanization dynamics in a non-ambiguous way, this approach should be further integrated with a multi-level analysis perspective, focused both on the role of strategies and political/ideological discourse at the macro level, and on the micro level dynamics of segmentation, polarization, and segregation. On a separate note, caution with regard to generalized assumptions about similarities should be adopted, taking into account the common characteristics of the two cities in terms of influence of post-socialist urbanization. Comparison with e.g. planned cities from the socialist period may lead to the identification of sharper differences.

\section{References}

Borén T., Gentile M. Metropolitan processes in post-communist states: an introduction // Geografiska Annaler. - 2007. - 89 B (2). - P. 95-110.

Frost I. Exploring varieties of (post)Soviet urbanization: reconciling the general and particular in post-socialist urban studies // Europa Regional. - 2018. № 25 2017(2). - P. 2-14. https://nbn-resolving.org/urn:nbn:de:0168-ssoar-59047-7. 
Golubchikov O. Interurban Development and Economic Disparities in a Russian Province // Eurasian Geography and Economics. - 2006. - N 47:4. P. 478-495.

Golubchikov O. The urbanization of transition: ideology and the urban experience // Eurasian Geography and Economics. http://dx.doi.org/10.1080/ 15387216.2016.1248461.

Grubbauer M., Kusiak J. (eds.). Chasing Warsaw. Socio-Material Dynamics of Urban Change since 1990. Campus Verlag GmbH, Frankfurt-on-Main.

Hirt S., Stanilov K. Regional study prepared for Planning Sustainable Cities: Global Report on Human Settlements 2009. http://www.unhabitat. org/grhs/2009

Soja E. The city and spatial justice. Spatial justice, 2009. N.1, September.

Sykora L., Stanilov K. The challenge of post-socialist suburbanization. In: Sykora, L., Stanilov, K. (eds.). Confronting Suburbanization: Urban Decentralization in Postsocialist Central and Eastern Europe. Chichester: Wiley, 2014.

Timar T., Varadi, M. M. The uneven development of suburbanization during the transition in Hungary // European Urban and Regional Studies, 2001. 8(4): 349360 .

Wiest K. Comparative Debates in Post-Socialist Urban Studies. Urban Geography, 33:6, 829-849. 